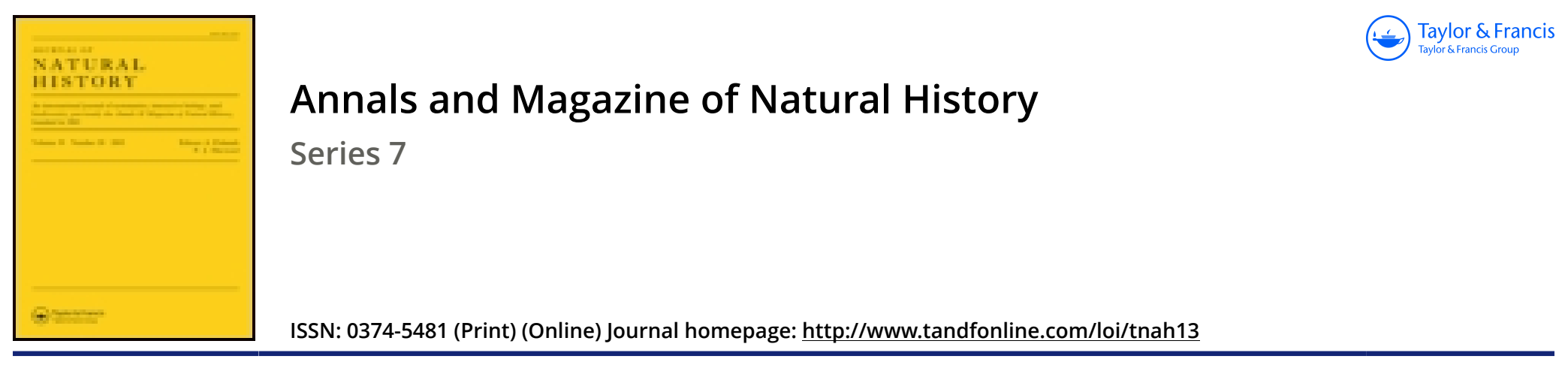

\title{
LXIII.-Relationships of the Rugosa (Tetracoralla) to the living Zoantheœ
}

\section{J.E. Duerden}

To cite this article:J.E. Duerden (1902) LXIII._Relationships of the Rugosa (Tetracoralla) to the living Zoantheœ, Annals and Magazine of Natural History, 9:53, 381-398, DOI: 10.1080/00222930208678607

To link to this article: http://dx.doi.org/10.1080/00222930208678607

册 Published online: 28 Sep 2009.

Submit your article to this journal $\sqsubset \pi$

Џ Article views: 5

Q View related articles $\sqsubset$

4 Citing articles: 7 View citing articles 진 
reach beyond the fourth and never attains the anal cell ; it is straight on both its borders.

Length $8 \frac{1}{2}$ millim.

One of the specimens from Borneo does not measure more than $6 \frac{1}{2}$ millim.

[To be continued.]

\section{LXIII.-Relationships of the Rugosa (Tetracoralla) to the living Zoantheo. By J.E. DuerdeN *.}

When briefly discussing, in 1871 , the Palæozoic corals included under Milne-Edwards and Haime's order Rugosa, the late Count Pourtalès thus remarks:- "Mr. R. Ludwig has shown (H. v. Meyer's 'Palæontographica,' vols. $x$. and xiv.) that the tetrameral arrangement claimed for the Rugosa is only apparent, there being originally six primary septa, but that further development in each system is asymmetrical, and that two of the systems remain generally undeveloped. I had, before having knowledge of Ludwig's researches, come substantially to the same conclusions by the examination of Lophophyllum proliferum, Edw. \& H., from the Carboniferous formation, a form very suitable for that study. . . . When the youngest stage of the coral is examined by cutting through the tip of the conical Lophophyllum proliferum, six primary septa and six interseptal chambers are found, placed symmetrically on two sides of a vertical plane, and anequally developed."

The very elaborate and painstaking researches of Ludwig and the above definite statement of Pourtalèz have apparently never been accorded the full consideration they deserve in any discussion of the affinities of the Rugosa. Supported by the conclusions of Kunth (1869), it seems to have been generally accepted by most students of this extinct group of corals that the adult arrangement of the septa around four principal members is sufficient evidence for assuming a primary tetrameral plan. The procedure is in some measure to be accounted for by the rarity with which the earlier stages in the growth of the septa of fossil corals are procured, and the difficulties involved in their investigation.

Tetramerism, both primary and secondary, has been the conception underlying most of the recent attempts which have

* From the 'Johns Hopkins University Circulars,' vol. xxi. No. 155, pp. 19-25 (Jan. 1902). 
been made to bring the Rugosa either into line with modern hexamerous corals, or to associate them with other groups; in the suggestions of Quelch (1886) and Ogilvie (1893), however, minor considerations of structure have prevailed. G. von Koch (1896), with his mature experience of coral morphology, has tried to show how from the six pairs of primary mesenteries, arranged as in recent corals, a primitive

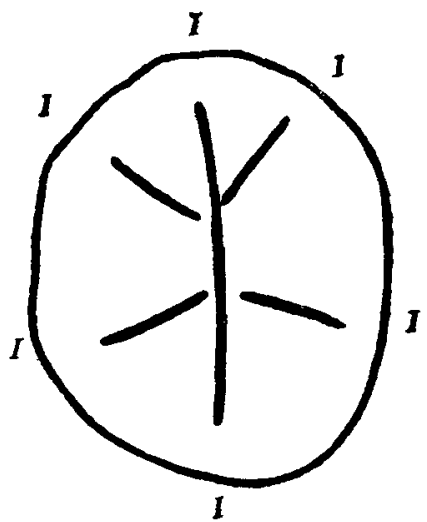

Fig. 1.

Tr susverse section through the tip of a corallum. The dark median lines of only six primary septa are present, but the ontlines of the septa as a whole are not clearly determinable, their surfaces being fused throughout. The two median septa are represented by a continuous line, while the other four septa are arranged as an upper bilateral pair and a lower bilateral pair. Of the six primary interseptal spaces, the two upper are slightly smaller than the others. By interseptal spaces may be here understood the interval between the dark lines of two contiguons septa; the septa are so broad as to occupy the whole of the calicinal cavity, leaving no interseptal loculi. The descriptive terms upper and lower are nsed merely to indicate the position of the parts in relation to the section as a whole, and can bave no morphological significance until the relationship of the different aspects of the coral with modern forms is established. In all the figures the upper border corresponds with the convex side of the coral and the lower with the concave border; the primary septa are indicated by the Roman numeral I. and the later septa by the letters A-D, according to their order of appearance within the four primary interspaces.

septal tetramerism might be obtained; while the distinguished Belgian naturalist E. van Beneden (1897), assuming a primary four-rayed condition, places the group near the tetrameral Scyphomedusa, far removed from the hexamerous Madreporaria and Actiniaria. 
Recently the Geological Department of the United States National Museum has generously prepared for me serial transverse sections of several species of Palæozoic corals*, for study in connexion with certain results upon the mesenterial and septal arrangement in Madreporaria. Among these

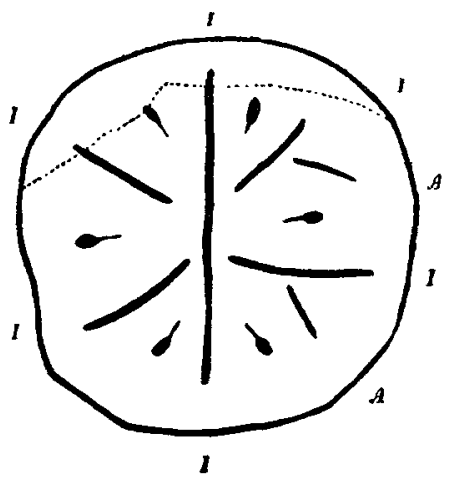

FIG. 2.

Transverse section through the tip of a second corallum, taken a little higher comparatively than the former section. The two median septa are still represented by a continuous line and the lateral boundaries of all the septa are partly indicated by small oval interseptal Inculi, which in the actual sections are filled with transparent calcite or some opaque matter. In the drawings the loculi throughout are represented as opaque. Within the middle and lower primary interseptal spaces on the right side occur the dark lines of two new secondary septa (A), but no trace of any is seen on the left side. It is not unusual in modern corals for the growth of one region to be slightly in advance of that in another. The interrupted line towards the upper border of the figure marks the outline of the actual section. In this and some of the other figures the sections represented had been slightly fractured at one region or another during their preparation; but in order to give somewhat of symuetry to the drawings I have attempted restorations of the outline, the actral boundaries being indicated by the interrupted lines.

are several specimens of Lophophyllum proliferum (McChesney), the species investigated by Pourtales. The fossils were collected from the Coal-Measures, Springfield, Ill., and the preservation, even to the tip, is very perfect, while the practical absence of internal vesicular tissue enables the septal arrangement to be followed with every degree of certainty.

The preparations enable me to assert that in each case the

* For the selection of the specimens and the supervision of the preparation of the sections I am indebted to Prof. C. Schuchert and $M_{2}$. T. Wayland Vaughan. 
section through the tip of the corallum displays the median $d r k$ lines of six primary septa, separated by six interseptal spaces. One example exhibits the six septa only (fig. 1), another shows two rudimentary secondary septa in addition to the primary six (fig. 2), while a third presents four secondary septa and the rudiment of a fifth (fig. 3). The sections thus confirm in the most complete manner the statement made by Pourtalès thirty years ago, and serve to establish beyond

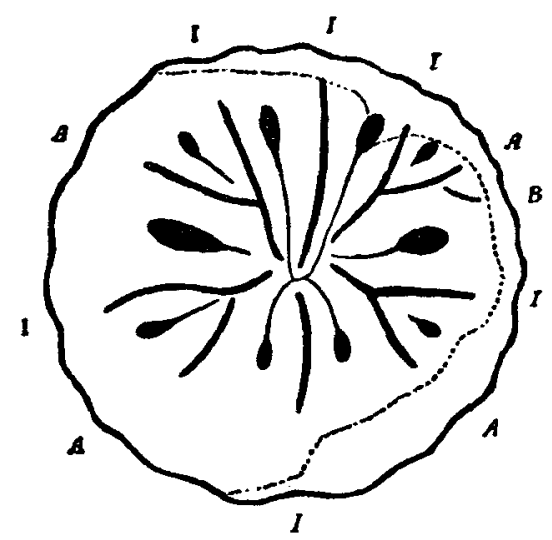

Fig. 3.

Transverse section towards the apex of a third corallum, taken at a little higher level than the two previous sections. The six primary septa are recognizable by their greater size, the outlines being indicated by the oval interseptal loculi and thin marginal lines; the two median septa are now distinet from one another, and the upper is larger than the lower, and is thereby already recognizable as the main or chief septum. The two upper primary interseptal spaces are much narrower than the middle and lower interspaces. Within each of the latter an additional septum (A) has appeared, and within the middle right interspace the rudiment of a second additional septum (B) occurs. No new septa are ever developed within the two upper interseptal spaces. As the calice increases in diameter the angle at which the primary septa are inclined to one another changes, owing to the intercalation of new septa at practically equal distances apart; hence the irregularity in form of the dark median line. In the inward growth of the new septa their inner extremities necessarily come into contact with the older septa already stretching as far as the middle, and thus give rise in lower sections to the appearance of branching. It is some time before all the septa become rearranged as true independent radii (cp. fig. 6).

a doubt the primary hexameral character of this one member of the Rugosa.

The six primary septa are represented in the sections at the tip of the fossilized coral as follows:-A single continuous 
median dark line, donoting the two axial or directive septa, and on each side of this two other dark lines, which represent two bilateral pairs of septa. In later sections the single median line becomes replaced by two nearly equal lines (fig. 3), which soon show the enormous difference in size characteristic of the "main" and "counter" axial septa of this species (fig. 4). In the earlier sections the actual

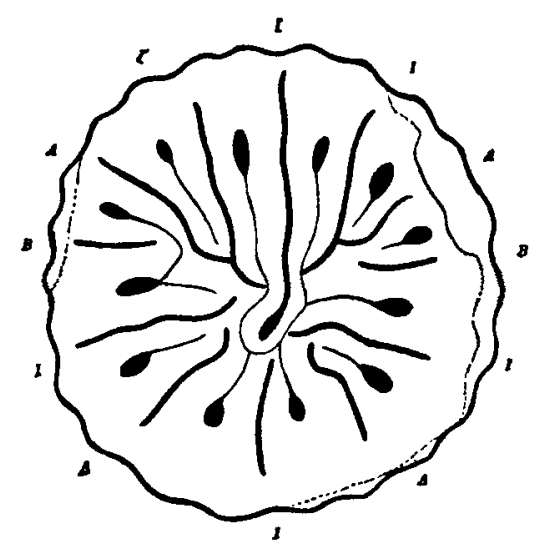

FIG. 4 .

Transverse section of the same specimen, taken still further from the apes than that represented in the former figure. The larger or chief septum now extends much beyond the centre of the nearly solid calice; the opposite or counter septum is comparatively small; two well-developed additional septa (B) occur within the middle interseptal space on each side. The superficial ridges and grooves are moderately well marked in the section, and reveal that the median dark line of each septum corresponds with a groove and that two ridges occur between every two adjacent septa.

boundaries of each septum are not recognizable, but in transmitted light the dark median line representing the centres of calcification is very distinct all the way.

It is also possible to determine the ultimate fate of the two bilateral pairs of primary septa. One pair forms the "alar" or lateral septa of palæontologists, while the two moieties of the remaining pair, recognized by Ludwig and Pourtales, but not accepted by Kunth, are disposed one on each side of the axial septum on the convex side of the calice.

The sections taken at a short distance above the tip indicate that the subsequent septa are added within only four of the six primary interseptal chambers or systems, according to Ann. \& Mag. N. Hist. Ser. 7. Vol. ix. 
the law first recognized by Ludwig, and also fully elaborated by Kunth, and likewise clearly indicated by Pourtales in the septal scheme given on p. 50 of 'Deep-sea Corals.' No new septa arise within the two remaining primary interseptal

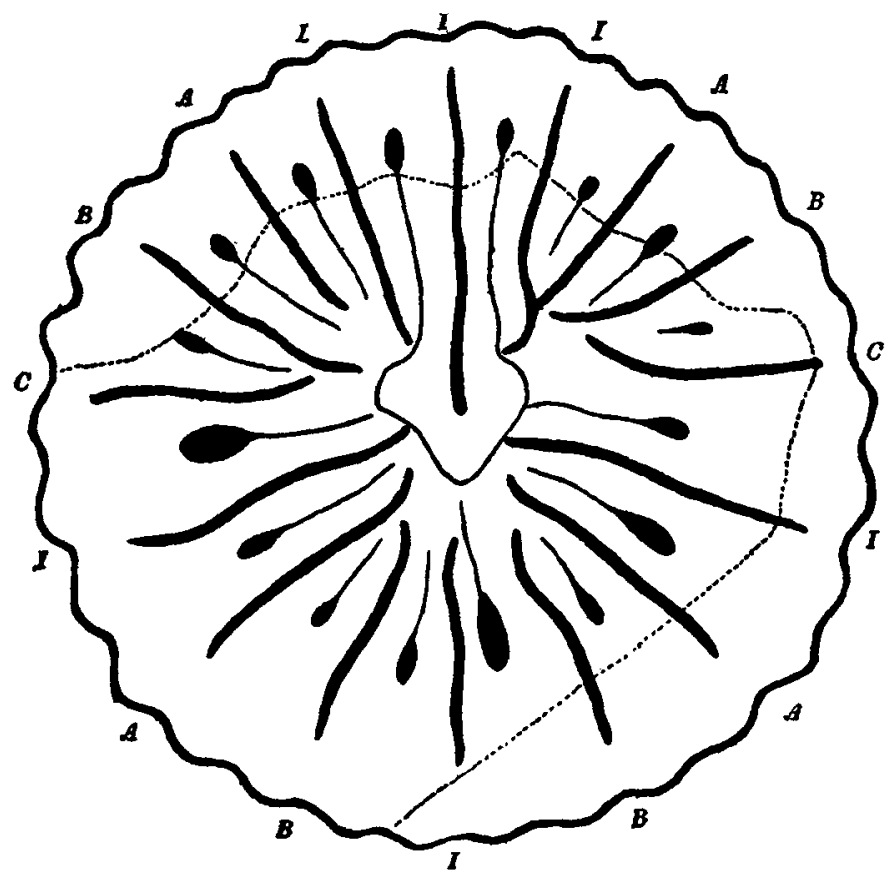

FIG. 5.

Transrerse section from the same coral taken about the middle of its length. Compared with the previous figure, an additional septum (C) has appeared within the middle chamber on each side and also within the lower chamber on each side $(B)$, so that now three secondary septa occur within each primary middle system and two within each primary lower system. Comparing all the figures thus far, the new septa of the former series are seen to always appear immediately next the upper aspect of the lower lateral primary septum on each side, and in the latter series on each side of the lower axial or counter septum. Each new septum is intercalated between a primary septum and the last-formed septum of the secondary series, in each case on the same aspect of the primary septum.

spaces. The sections further reveal that the small septa, which in the mature coral alternate with all the larger or principal septa, do not make their appearance until the growth of the calice is nearly completed. From what is known of 


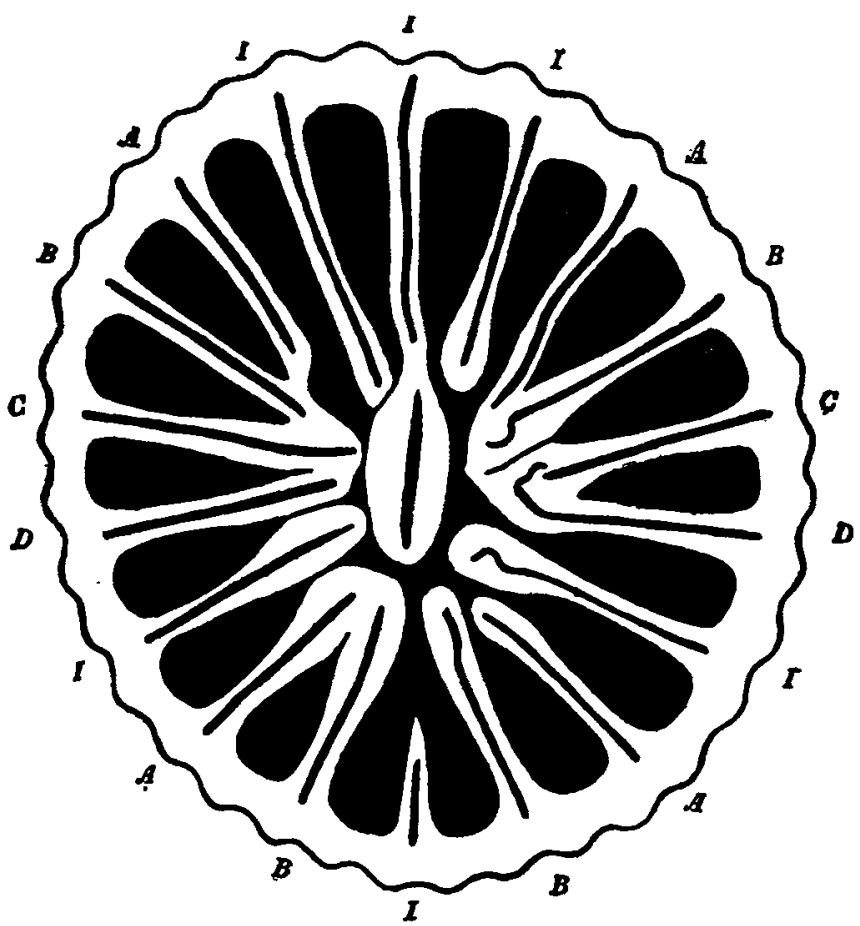

Fia. 6.

A transverse section taken towards the upper part of the same corallum as before. The septa are now comparatively thinner, and wide interseptal chambers occur. The former are yet swollen aud partly fused at their inner extremity. The chief septum is enlarged at its middle extremity, constituting a nearly free columella, and the counter septum is greatly reduced. Compared with the previous section, an adảitional pair of septa occurs (D), but, excepting the two axial septa, the different members are so nearly alike in size as to render it impossible to determine from this source alone whether the new pair has arisen within the middle or the lower systems. A serial section, coming somewhat earlier, but too much fractured to be drawn with the camera, shows distinctly a very small septum on the upper aspect of the lower pair of primary septa, and in this later section 1 interpret them as being represented by the septa, D, D. All the sections indicate that growth proceed 3 more rapidly within the middle system than within the lower. Four bilateral pairs of secondary septa now occur within the middle systems, and only two bilateral pairs within the lower systems. Some variation exists in the different calices with respect to the number of septa arising in each system, but in most mature calices of the species four new pairs of septa are developed within the middle systems and three pair within the lower systems. 
the relationship of the septa to the mesenteries in modern corals, the larger septal series evidently appeared within the entocolic chambers of the polyps, while the smaller septa are exosepta. In the early stages of recent corals it is not unusual for the entosepta to appear in advance of the exosepta; but the interval would appear to have been enormously exaggerated in the present form, until, in fact, the full complement of entosepta had appeared.

Not only are the serial transverse sections of $L$. proliferum favourable for the establishment of the primary condition of the septa, as well as the sequence of the later members; but the results can be confirmed in a most definite manner from the well-defined ridges and grooves occurring on the outer surface of the corallum. Sections through the lower part of the coral demonstrate that two external ridges correspond with each internal interseptal space, and each alternate groove corresponds with a septum; in the upper part of the calice, where the cycle of small septa has appeared, each ridge then corresponds with a single interseptal space, and each groove with a septum (cp. figs $6 \& 8$ ). On speciniens of which the tip and the external surface of the coral are well preserved twelve grooves and ridges, representing the six primary septa and interseptal spaces, occur practically as far as the apex, and can be followed all the way upwards, and the successive intercalation of the later septa at four regions can also be observed (figs. 9, 10).

All the more recent studies on the Anthozoa indicate that the order of appearance and adult arrangement of the mesenteries are the surest guide to a phylogenetic or natural classification. In the divisions Actiniaria and Madreporaria, including the sea-anemones and corals, two sharply distinguished stages in the appearance of the mesenteries are to be recognized, the one embracing the development of the six primary pairs of mesenteries (protocnemes) and the other the development of all the later mesenteries (metacnemes). With a few exceptions the order of establishment of the six pairs of protocnemes is the same throughout the Actiniaria and Madreporaria, denoting these two to be a well-defined, primitively hexamerous group. With the appearance of the later mesenteries, however, divergences are introduced which are to be regarded as of the most fundamental importance in actinian and coral morphology.

Three distinct types of metacnemic succession are recognizable. In by far the majority of recent corals and anemones the new mesenteries arise successively as unilateral pairs within each of the six primary exocœlic chambers, and in the 
end constitute alternating hexameral cycles; in the Zoantheæ, as the researches of von Koch (1880), Erdmann (1885), and many others have shown, the new mesenteries are developed at only two regions, the exoccele on each side of the ventral directives, and the adult polyps are strongly bilateral (fig. 12); in the perforate corals Porites and Madrepora I have recently found that the mesenteries beyond the six primary pairs appear as bilateral pairs within the directive or axial entocceles, thus recalling the method of mesenterial growth characteristic of the Cerianthidea after the formation of the first four pairs (1900).

It remains to be seen how close the septal conditions occurring in Lophophyllum can be brought into relationship with those of modern corals or the mesenterial plan of Actinians. The late Prof. H. de Lacaze-Duthiers (1873, $1897)$ and G. von Koch $(1882,1897)$ have described the primary stages in the formation of the corallum of living species of Astroides, Caryophyllia, \&c., and in all cases either six or twelve septa are formed simultaneously; in the course of the postlarval development of the West-Indian corals Maricina areolata, Favia fragum, and Siderastroea radians I have also found that six septa first appear, arising within the entocœlic chambers of the six primary pairs of mesenteries. Thus the protosepta are hexameral in all the representatives of the three sections of living corals-Aporosa, Fungacea, and Perforata-whose early development has been followed.

As far as the protoseptal stage, therefore, the hexameral plan of its primary septa at once places the Palæozoic Lophophyllum in agreement with recent Madreporarian corals, and renders unnecessary any attempt to account for a primitive tetramerism.

It is otherwise, however, with the subsequent stages of development. Very few observations have been made upon the actual manner of appearance of the secondary septa in corals; but in practically all modern species the septa beyond the primary six are found disposed within the six interspaces separating the primary members, and ultimately they are radially arranged in regular alternating hexameral cycles, just as are the mesenteries. Certain exceptions to this general plan occur, but do not in any way introduce any distinct fundamental type, except in the case of the genera Porites and Madrepora, where new septa arise within the axial or directive entocoles-that is, in the position occupied by the primary axial septa.

The later septa in Lophophyllum, as in most other Zaphrentoid corals, arise bilaterally within only four of the six primary 


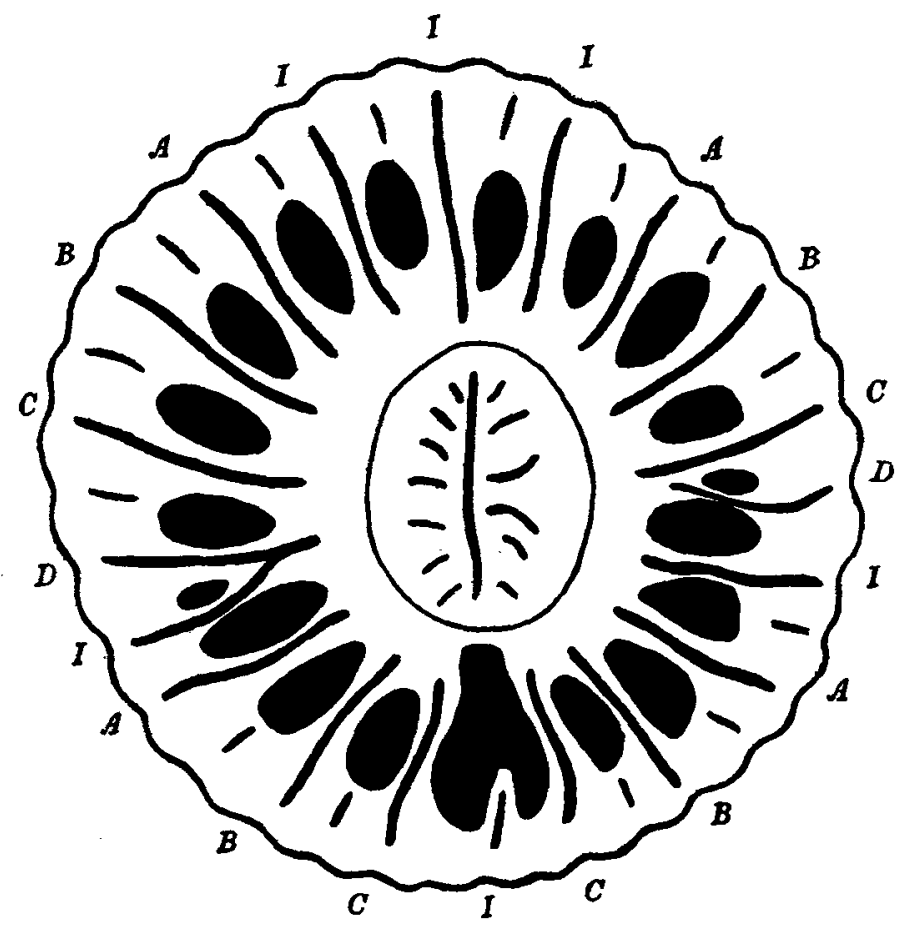

Fig. 7.

Transverse section towards the upper regiun of a fourth individual coral before the projecting columella becomes free from the eopta. The middle of the section is occupied by the Iarge columella with which the septa are fused; the different centres of calcification show that the columella at this region is formed of the fused enlarged middle extremities of the chief septum and the lateral septa. The section is of particular interest as showing the late appearance of the small alternating septr. In all the previous sections no trace of these was present, but they are here represented by dark centres of calcification within the thickened thecal wall. A septum occurs between every two adjacent larger septa, so that the total number of septa now corresponds with the number of superficial grooves; in higher sections and in mature corallites the small septa are seen as distinct projections from the inner surface of the wall. The additional smaller septa therefore appear practically simultaneously, and only when growth is nearly completed ; they have thus no sequence value whatever; only the larger septa are of importance in this direction. The section already shows the formation of the septal foseula by the coalescence of the two interseptal chambers, one on each side of the counter septum.

interspaces, and in the adult never assume a crclical arrangement, but remain bilateral. It is the first characteristie which fundamentally distinguishes the form from any known 
modern coral, and in any natural taxonomic arrangement must call for its sharp separation as the representative of a distinct group. Though agreeing as concerns the protoseptal stage, the metaseptal sequence shows Lophophyllum and modern cyclical corals to be widely divergent.

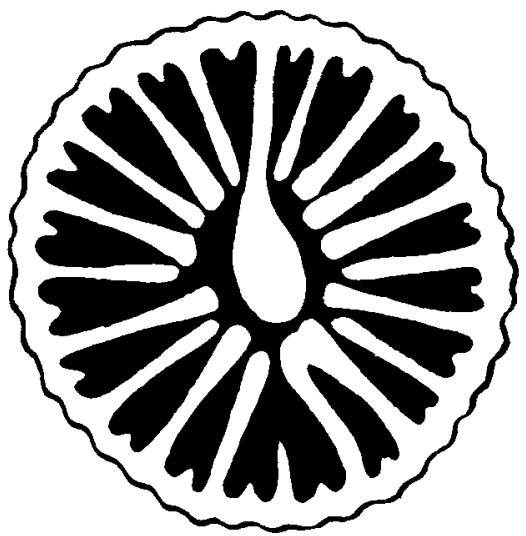

Fig. 8.

Upper surface of a polished specimen, showing the alternating small septa, which occur only towards the upper region of the calice. The principal septa, with the exception of the main and counter axial septa, are now practically equal in size and radially arranged, presenting little evidence of their successive origin in bilateral pairs. In such a figure it is impossible to determine the ordinal value of the septa, but the total number present agrees with that in the previous figure. The dark median lines are not seen by reflected light.

The Palæozoic corals sufficiently resemble those of modern days to warrant the assumption that the general relationships of the polyp to the corallum were the same as those now fully understood, and therefore, knowing their septal sequence, we can assume what must have been the mesenterial. With such a metaseptal sequence as that above demonstrated, both by the serial sections and by the external ridges and grooves, modern coral morphology permits the assertion that in the polyps of Lophophyllum new mesenteries were successively developed within four of the primary exocolic chambers, and at only one region in each, immediately next a primary pair of mesenteries. Though no known living coral presents such a mesenterial sequence, yet it bears the closest resemblance to what is found to be characteristic of Zoanthid polyps, except that here the mesenterial increase takes place in only two exoccelic chambers, whereas in Lophophyllum the process was carried on in four chambers. The researches of $E$. van 
Bfneden (1890) and McMurrich (1891) have established that the protocnemic stage in the Zoanthids is hexameral, and such must also have been the case with the extinct coral; the metacnemes arise in succession within two exocoelic

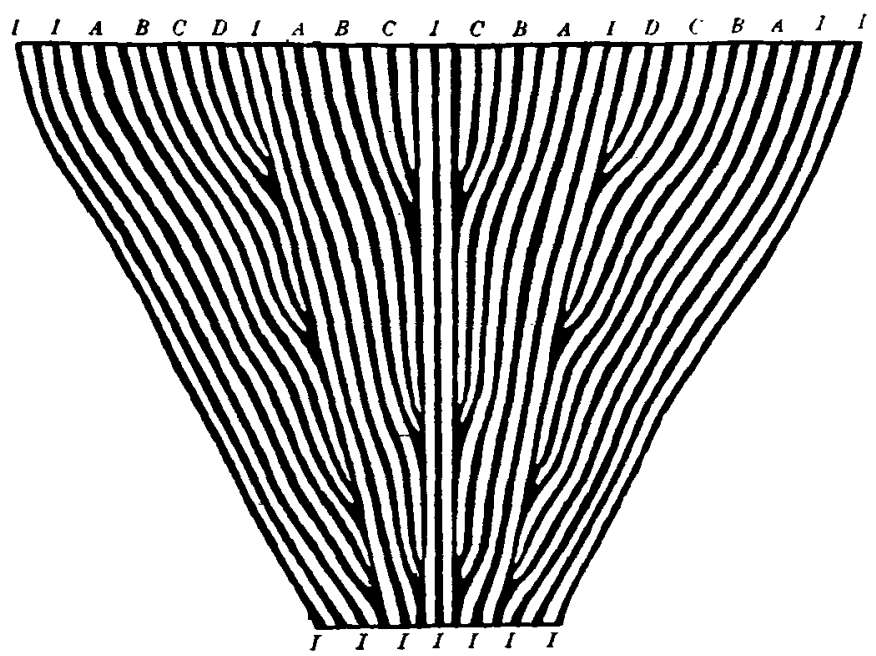

Fio. 8.

Diagrammatic representation of the grooves and ridces occurring on the external surface of the thecal wall. The black lines represent the grooves, the intervening spaces the ridges. The coral is supposed to have been opened vertically along its convex border, and fattened out and viewed from the concave side. The sections have shown that the larger septa correspond only with alternate grooves; hence new ridges always appear in pairs, not singly. The middle line corresponds with the small counter septum, the one on each side of this with the small septa, one on each side of the counter septum. New septa have been added successively on each side of the counter septum, alwars at one region, so that as new members appeared the older have been pushed further away. In the present instance three principal septa (A, B, C) bave appeared on each side of the counter septum, between it and the lateral or alar primary septum. In the space between the lateral primary septum on each side and the dorsal lateral septum four principal septa (A, B, C, D) have arisen in succession, in each case in the region immediately beyond the alar or lateral septum. No septa bave appeared between the upper lateral primary septa and the main septum. Only twelve ridges and twelve grooves continue as far as the apex of the coral, representing the primury six septa and their interspaces.

chambers in Zoanthids, in the coral they appeared successively within four similar chambers. In Zoanthids the incompletion of the directives at one axial extremity and their completion at the other extremity may with good reason be correlated with the usual difference in size between the main 
and counter septa of the Rugosa; also some such relationship may perhaps hold between the complete (macrotype) or incomplete (microtype) sixth protocnemic pair and the onlarged or diminutive alar septa. The presence of a gonidial groove at one extremity of the stomodeum in the Zoanthids and its absence from the other border still further conform with the marked difference between the two extremities in the Rugose coral (cp. figs. 8 \& 12).

The ontogeny of Lophoplyllum proliferum, both in its primary and secondary phases, is thus in fullest agreement with the history of living types known to the actinologistnot, it is true, with any coral type, but with a group of the closely related Actiniaria. So far as Lophophyllum can be taken as a representative, the peculiar septal plan of the Rugosa introduces no new conception into Anthozoan studies, and any other peculiar features which the order possesses, such as tabule and vesicular endotheca, are of very subordinate morphological importance compared with the septal scheme.

A comparison of the septal plan in L. proliferum with the numerous figures of Zaphrentoid corals given in the works of Ludwig and Kunth reveals a unity of arrangement in very many cases, and from the scanty evidence yet adduced there is no reason to suppose that the primary septal plan was in anyways different from that here established, though in many cases actual proof mas not be forthcoming. Kunth everywhere assails the hexamerism of Ludwig, yet he nowhere produces direct evidence of a primary tetrameral condition; indeed, I have not come upon any figure by any author representing a section of a primary four-rayed condition in the Tetracoralla. The converse is, however, true. Both Duncan (1867) and Kunth (1869), apparently independently, have found certain species of the Palæozoic Heterophyllia ro be primarily hexamerous. As a result of this the former writer connects them with the Mesozoic and recent Astræidæ, though acknowledging that certain of their other characters ally them to the Cyathophyllidæ. There now seems every reason to suppose that the primary hexamerism of Heterophyllia is to be associated with that of Lophophyllum and that the subsequent development follows the same essential plan in both. It is impossible to accord the same treatment to Lophophyllum as that to which Heterophyllia has been subjected; in the former the addition of the metasepta according to Kunth's law effectually prevents any suggestion of an Astræan character. Considering how universal is the hexameral protocnemic stage in modern corals and anemones, it would not be surprising to find it a fundamental characteristic of the Madreporaria of Palæozoic times. 
F. Frech (1885) has also described and figured a new genus and species of Rugose coral, Decaphyllum Kreneni, in which the smallest specimens possess six large and six small alternating septa, exactly recalling the protoseptal stage of modern hexamerous corals. In the fully dereloped corallites an additional pair of septa has appeared within the two primary systems towards each axial border. Frech considers two opposite members of the smaller cycle to represent the main

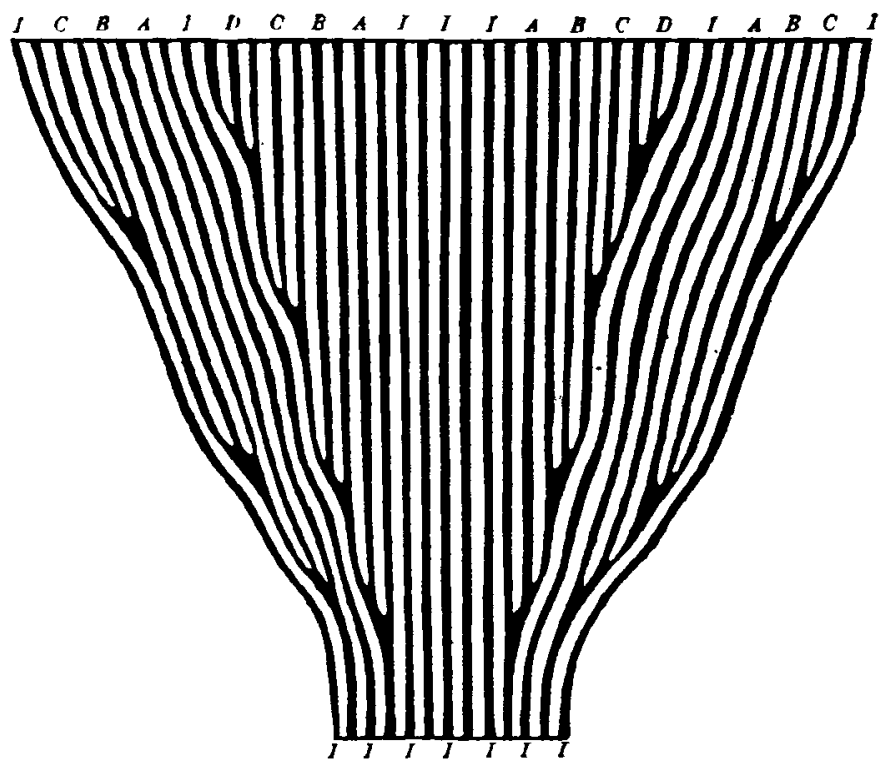

Fio. 10.

Diagrammatic representation of the superficial ridges and grooves of the same coral as before, seen from the convex aspect. The coral is supposed to be laid open along its concave border and then flattened. The main septum is represented by the middle line and the counter septum by the boundary line at each lateral extremity of the figure. The other septa are as before, only the order is reversed.

(Hauptseptum) and counter (Gegenseptum) septa, and attempts to derive the later stages according to Kunth's law of septal increase. Considering the septa, however, from the standpoint of modern coral morphology, the members of the small cycle are undoubtedly exosepta, and can scarcely be regarded as axial or possess much value as indicating septal sequence.

In a later paper Frech $\left(1885^{\mathrm{a}}\right)$ has attempted to derive a primary tetrameral septal plan from the different mesenterial 


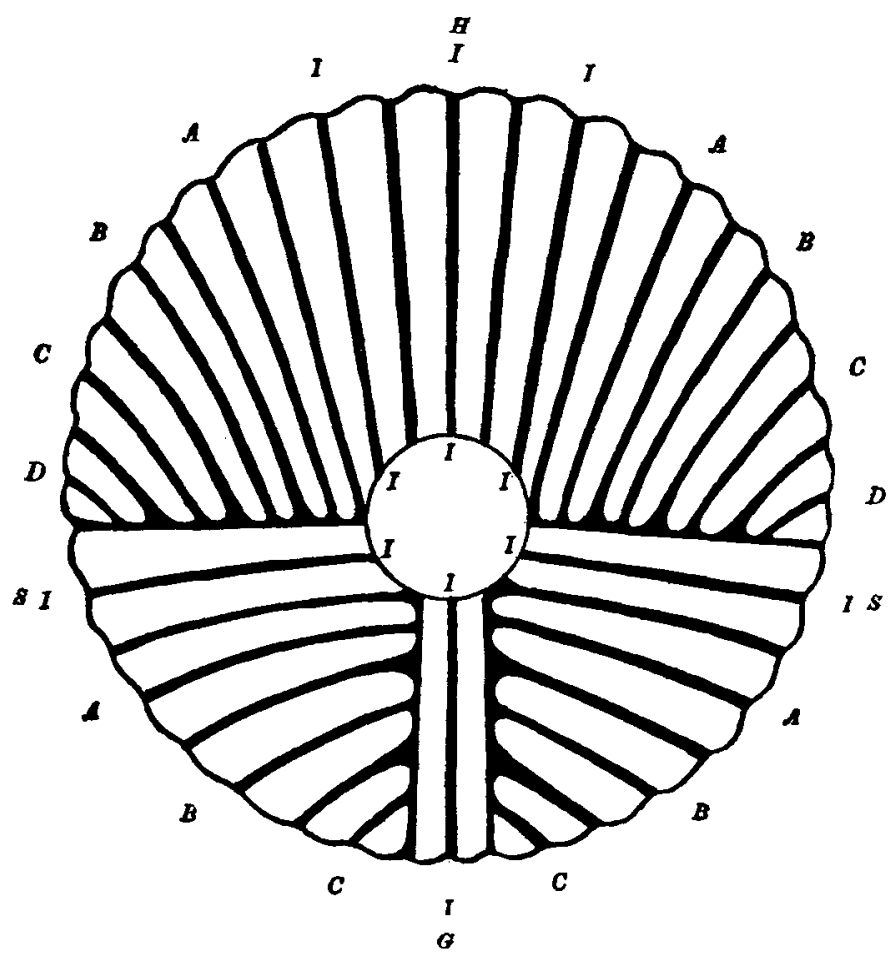

Fro. 11.

Diagrammatic representation of the ridges and grooves on the calicinal wall, as seen from below. The upper border of the figure corresponds with the convex side of the coral and the lower with the concave. The apex is represented as a circular area, instead of as a point, in order to better indicate the twelve primary ridges and grooves, which extend thus far. On each side of the upper half the secondary septa (A, B, C, D) appear as radiating from the alar septum (S), the oldest lying next the primary septum adjacent to the main septum $(\mathrm{H})$; on each side of the lower half the septa $(A, B, C)$ radiate from the counter septum (G), the oldest lying next the alar septum.

Comparing the schematic figure with that of Streptelasma given by Kunth (1869, p. 647) and copied into most of the text-books on palæontology, it will be seen that the positions at which the septa are added in Lophophyllum are the reverse of those in Streptelasma. In the latter genus, as appears to be also the case in most Zaphrentoids, the new septa in the main quadrant are added immediately on each side of the main septum, the oldest being next the alar septu; while in the counter quadrants they are added immediately adjacent to the alar septa, the oldest being next the counter septum. 
stages in the development of Actinian larvæ as presented by Lacaze-Duthiers in 1873. In doing so, however, he assumes septal and mesenterial relationships differing from any yet established in Zoantharian morphology.

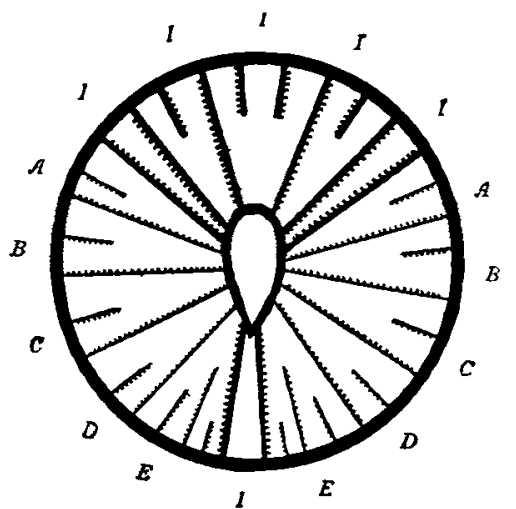

FIo. 12.

Diagrammatic representation of the mesenteries in a macrutypic Zoanthid. Five pairs of primary mesenteries, represented by thicker lines, occur at the dorsal aspect of the polyp, while the pair of sulcar directires is ventral. New mesenteries, represented by fainter lines (A-E), are added in succession within the exocolic chamber on each side of the rentral directives, the oldest (A) being next the dorsal group of primary mesenteries. It will thus be seen that in the living Zoanthids new mesenteries are successively added at only one exocoelic region on each side of the polyp, while in Lophophyllum they were added at two regions on each side. The entocoelic chanber of the incomplete dorsal pair of directives in the Zoanthids will correspond with the large chief septun of Lophophyllum, and the entocoele of the complete ventral pair of directives, enclusing the siphonoglyph or gonidial groove, will corre: pond with the small counter septum and septal fossula of Lophophyllum.

The most recent studies of the Actiniaria and Madreporaria tend to establish a wide division between ordinary anemones and corals, with a cyclical arrangement of the mesenteries, and the Zoanthids and Cerianthids, with a strongly bilateral symmetry. The separation is really founded upon the mode of origin of the metacnemes in the three groups, adult symmetry in the Zoantharia counting for little compared with developmental history. The tendency is to regard each of the three groups as lanking in importance with any of the other great divisions of the Anthozoa, such as the Alcyonaria and Antipatharia. Considerations along such lines have induced van Beneden (1897) to remove the Ceriantheæ altogether from their usual association with the Actinians, to niake of them an order Ceriantharia, and to place them along with the Antipatharia under a single division, Ceriantipatharia. 
It is quite certain that the Rugose corals with a metaseptal sequence at all resembling that of Lophophyllum cannot be associated with other corals, recent or extinct, in which the metasepta arise within all the primary exoccles; nor can they be placed along with the Cerianthex, where growth is axi 1 , as was suggested by Lindströ $n$ in 1868. As already pointed out by Neumayr (1889), the considerations which induced Quelch, in his report on the 'Challenger' reefbuilding corals, to class the Rugosa with modern Aporosa are altogether of secondary importance, and the same must be said of the attempt of Ogilvie (1896).

Supremacy being accorded the manner of mesenterial development as indicating natural relationships, the bilateral Zoanthids, primarily hexameral, but with their metacnemic development restricted to two exocolic regions, are, more than any other Anthozoan type, the modern representatives of the Rugosa. The Zoanthids, like the reef-corals with which they live associated, flourish to-day only in trupical seas; they would seem to represent an old-fashioned Actinian type which has been preserved as a result of the habit of forming an incrusting skeleton and often compact colonies. In the past they no doubt bore much the same relationship to the Rugose polyps which the ordinary Actinians of to-day do to the majority of recent corals.

The following arrangement will best indicate the different fundamental types of metacnemic sequence now known within the Actiniaria and Madreporaria and the position amongst them of the Rugosa. With the exception of the Cerianthex all possess a primary hexameral stage, consisting of six pairs of mesenteries with six primary entocoelic chambers and six primary exocoelic chambers. Calcareous septa may appear within only one or both series of chambers. It is in the succession of the later mesenteries and septa-metacnemes and metasepta-that the divergences are introduced.

1. The metacnemes arise as unilateral pairs at one, three, seven, \&c. regions within all the six primary exocceles, and become arranged in one, two, three, or more cycles:

a. Non-skeletal.

Most Actinians. b. Skeleton-forming.

Most recent Madreporarian corals.

2. The metacnemes arise as bilateral pairs at only one region within two or more of the primary exocoles:
a. Non-sieletal.
Zoanthids.
b. Skeleton-forming.
Lophophyllum and probably other Rugosa.

3. The metacnemes arise as bilateral pairs at one region within one or both of the axial entocoles :
a. Non-skeletal.
b. Skeletan-forming.
Cerianthids.
Porites, Madrepora. 


\section{References.}

1862. Ludwig, R. "Actinozoen und Bryozoen aus dem Carbon-Kalkstein im Gouvernement Perm," Palæontographica, $x$.

1865. - "Corallen aus Paläolithischen Formationen," Palæontographica, xiv, 1865-66.

1867. Duncan, P. M. "On the Genera Heterophyllia, Battersbyia, Palcocychus, and Asterosimilia," Phil. 'Trans. clvii.

1869. Kunth, A. "Beiträge zur Kenntniss fossiler Korallen," Zeitsch. der deutsch. geol. Gasellsch. xxi. 1869, xxii. 1870.

1871. df PourtalEs, L. F. "Deep-sea Corals," Illustr. Catalogue Mus. Comp. Zool. Harvard College, iv.

1873. LAcazk-DUthIers, H. DE. "Doveloppement des Coralliaires. Deux. Mém. Actiniaires à Polypiers," Arch. de Zool. Exp. et Gén. ii.

1880. voN KocH, G. "Notizen über Korallen," Morph. Jahrb. vi.

1882. ㄴ. "Ueber die Entwicklung des Kalkskeletes von Asteroides calycularis und dessen morphologischer Bedeutung," Mitt. a. d. zool. Stat. zu Neapel, iii.

1885. Frrch, F. "Die Korallenfauna des Oberdevons in Deutschland," Zeitsch. der deutsch. geol. Ges. xxxvii.

1885. . "Ueber das Kalkgerüst der Tetrakorallen," Zeitsch. der deutsch. geal. Ges. xxxvii.

1885. Erdmann, A. "Ueber einige neue Zoantheen," Jenaische Zeitschr. xix.

1886. QueLCH, J. J. "Report on the Reef-Corals," 'Challenger' Reports, Zoology, xvi.

1889. Nrumayn, M. 'Die Stämme des Thierreiches,' $i$. Wien und Prag.

1890. van Benkdne, F. "Une Larve voisine de la Larve de Semper," Arch. de Biologie, $x$.

1891. MCMURRICH, J. P. "Contributions on the Morphology of the Actinozon.-III. The Phylogeny of the Actinozon;" Journ. Morphol. v.

1896. voN KocH, G. 'Das Skelett der Steinkorallen.' Leipzig.

1896. OaInvm, M. "Microscopic and Systematic Study of Madreporarian Corals," Phil. Trans. clxxxvii.

1897. von Koch, G. " Entwicklung von Caryophyllia cyathus," Mitt. a. d. zool. Stat. zu Nerpel, xii.

1897. van Beneden, E. "Les Anthozorires de la Plankton-Expédition," Résultats de la "Plankton-Expedition der HumboldtStiftung," ii. Kiel et Leipsic.

1897. Lacaze-Duthizers, H. De. "Faune du Golfe du Lion. Coralliaires. Zosntheires Sclérodermés," Archiv. de Zool. Exp. et Gén. 3 sér., v.

1900. Dumndin, J. E. "Order of Appearance of the Mesenteries and Septa in the Madreporaria," Johns Hopkins University Circulars, xix. no. 146.

\section{BIBLIOGRAPHICAL NOTICE.}

The Foraminifera: an Introduction to the Study of the Protozoc.

By Frederick Chapman, A.L.S., F.R.M.S., Palæontologist, National Museum of Melbourne. With numerous Illustrations. 8vo. Pp. xx \& 354. Longmans, Green, \& Co., 1902. Price 9s. THE publication of this new manual of the Foraminifera must be very gratifying to both the biologist and the geologist. To the former the natural relationships and the life-history of the 